\title{
2014 Dahlberg Award Winner: The effects of dietary toughness on occlusopalatal variation in savanna baboons
}

\author{
Evan Muzzall ${ }^{1}$, Ryan M. Campbell ${ }^{1}$, Meadow Campbell ${ }^{1,2}$, and Robert S. Corruccini ${ }^{1}$ \\ ${ }_{1}^{1}$ Department of Anthropology, Southern Illinois University, Carbondale, IL 62901 \\ 2Department of Anatomy, Southern Illinois University School of Medicine, Carbondale, IL 62901
}

Keywords: Diet, occlusopalatal variation, savanna baboons

ABSTRACT This study investigates the relationship between dietary toughness and craniofacial variation in two groups of savanna baboons. Standard craniofacial and malocclusion data were collected from a captive, soft-diet experiment group $(n=24)$ and a sample of wild-captured baboons, raised on tougher, natural foods $(n=19)$. We tested the hypothesis that in the absence of normal masticatory stress experienced during the consumption of wild foods, the captive baboons would exhibit higher

Malocclusions are the improper growth, positioning, and/or alignment of the teeth and jaws that lead to irregularities in occlusal surface contact and abnormalities of the surrounding bony structures. These deviations are due to multiple factors, but the reduced masticatory demands of modern diets have shown considerable influence (Corruccini, 1984; 1999; Corruccini et al., 1983; Corruccini and Lee, 1984; Varrela, 1990, 1992, 2006; Evensen and Øgaard, 2007). Notably, alterations in the proper growth trajectories of these areas due to decreased chewing forces are not unique to humans. By controlling for diet, laboratory animal studies have contributed to a broader understanding of occlusofacial variability (Beecher and Corruccini, 1981a, b; Corruccini and Beecher, 1982; Larsson et al., 2005; Grünheid et al., 2009; Jašarević et al., 2010; Ravosa et al., 2010; Dias et al., 2011; Makedonska et al., 2012).

This study expanded on the research of Corruccini and Beecher (1984), who found reduced facial growth, decreased structural correlations, narrower faces, and more occlusal irregularities in savanna baboons fed a soft diet. Using the same soft-diet sample as Corruccini and Beecher (1984), but a different research design and a wild comparative sample, the present study contrasted craniofacial and occlusal data between two groups of savanna baboons fed diets that differed in their mechanical properties. This study tested the hypothesis that in the absence of natural food consumption, the soft-diet baboon sample would exhibit higher levels of facial and dental structural irregularities. Principal component analysis indicates separation of the two samples. The soft-diet sample exhibits significantly shorter palates, greater variability in palate position, and higher frequencies of occlusal irregularities that correlate with the shorter palates. Results offer further support that long-term dietary chewing stresses have a measurable effect on adult craniofacial variation.

levels of craniofacial variation due to their reduced chewing demands.

\section{MATERIALS AND METHODS}

The soft-diet experiment group consisted of 24 male Papio cynocephalus skulls housed at Southern Illinois University Carbondale. As part of a biomedical study in the 1970s, these individuals were fed "a very soft, atherogenic diet consisting of cholesterol, lard, butter, egg yolks, and powdered chow" for the last 27 months of their dental maturation (Corruccini and Beecher, 1984:136). Eighteen male $P$. anubis and one male $P$. cynocephalus individual housed at the Field Museum of Natural History were selected to be the wild-diet control sample because of their wild African origin. Although their exact diet was not known, their natural wild foods consist of grasses, roots, plants, leaves, bark, gums, seeds, fruit, berries, corn, small invertebrates, and even sheep and goats (Post, 1981; Barton, 1993; Wahungu, 1998; Akosim et al., 2010; Johnson et al., 2012). Visually, all individuals were dentally mature and had erupted third molars to suggest ages around 6-8 years (Phillips-Conroy and Jolly, 1988).

Correspondence to:

Evan Muzzall, Dept. of Anthropology, Southern Illinois University, Faner Building, Rm. 3525, 1000 Faner Dr., Carbondale, IL, 62901

Email: muzzall@siu.edu

Telephone: (618) 536-6651 
Members of genus Papio are possibly populations of a single species and are sometimes referred to as Papio hamadryas cynocephalus and P. hamadryas anubis to reflect this subspecies distinction. P. cynocephalus and P. anubis have been known to interbreed (Samuels and Altmann, 1986; Alberts and Altmann, 2001; Charpentier et al., 2008; Tung et al., 2008) despite geographical distinctions in their genetic compositions (Williams-Blangero et al., 1990; Zinner et al., 2013). Further, Frost et al. (2003) noted cranial morphological clinal organization of genus Papio in Africa. Northern baboons (like $P$. anubis) exhibit broader, less flexed crania and rostra compared to the southern forms (such as $P$. cynocephalus) that display inferiorly flexed and narrower crania and rostra (Frost et al., 2003:1056, 1069). Because of their clinal organization and similar environments, general shape differences between these two groups observed by Frost et al. (2003) likely reflect genetic differences.

Linear measurements consisted of standard craniofacial measurements (Moore-Jansen et al., 1994) and posterior airway maximum lengths and breadths (Fig. 1, Table 1). These data were recorded using spreading and sliding Mitutoyo calipers calibrated to $0.01 \mathrm{~mm}$. Principal component analysis (PCA) was used to identify measurement loadings responsible for driving the observed variation. Pearson's product-moment correlation coefficient was used to analyze the strength of correlation between measures identified by the PCA.

Occlusal data (Table 2) consisted of molar class relationships (Angle, 1899), posterior crossbite, rotations, displacements, and incisor overbite and overjet following the summation in Harris and Corruccini (2008). For the purposes of our study, we reduced occlusal scores to a score of 0 for normal occlusion and 1 for any deviation from normal oc- clusion in each category. These values were summed to estimate the magnitude of occlusal irregularity for each individual, and significant differences between the samples were calculated using a Mann-Whitney U test.

Spearman's rank correlation coefficient tested for associations between relevant linear measures and occlusal scores. To attempt to account for potential variation in body size, shape ratios were calculated by dividing all linear measurements by foramen magnum breadth (simplified from area calculations found in Radinsky, 1967; Gould, 1975). The raw and scaled datasets produced highly similar results so that the data quality appears to be high, and only the scaled data are reported here. Statistical analysis was conducted by RMC using the R Project for Statistical Computing (R Core Team, 2013) and PAST: Paleontological Statistics software (Hammer, Harper, and Ryan, 2001).

\section{RESULTS}

The PCA results indicate that the combined first two principal components account for $81 \%$ of variation within the sample (Fig. 2). The first principal component (PC1) indicates a size increase, primarily in the measures with the highest loadings, along that axis (Fig. 3). There was clear separation between the wild-diet (maroon circles) and softdiet (blue circles) samples primarily along the second principal component (PC 2). The loadings for PC 2 (Fig. 3) suggest that palate length (PAL) and incisivion (most distal point in the incisive foramen) to basion (IFB) distance contributed most to variation along this axis. Importantly, the single wild-diet P. cynocephalus (red circle) groups with the wild-diet $P$. anubis sample rather than the soft-diet $P$. cynocephalus sample, which suggests that the variation along

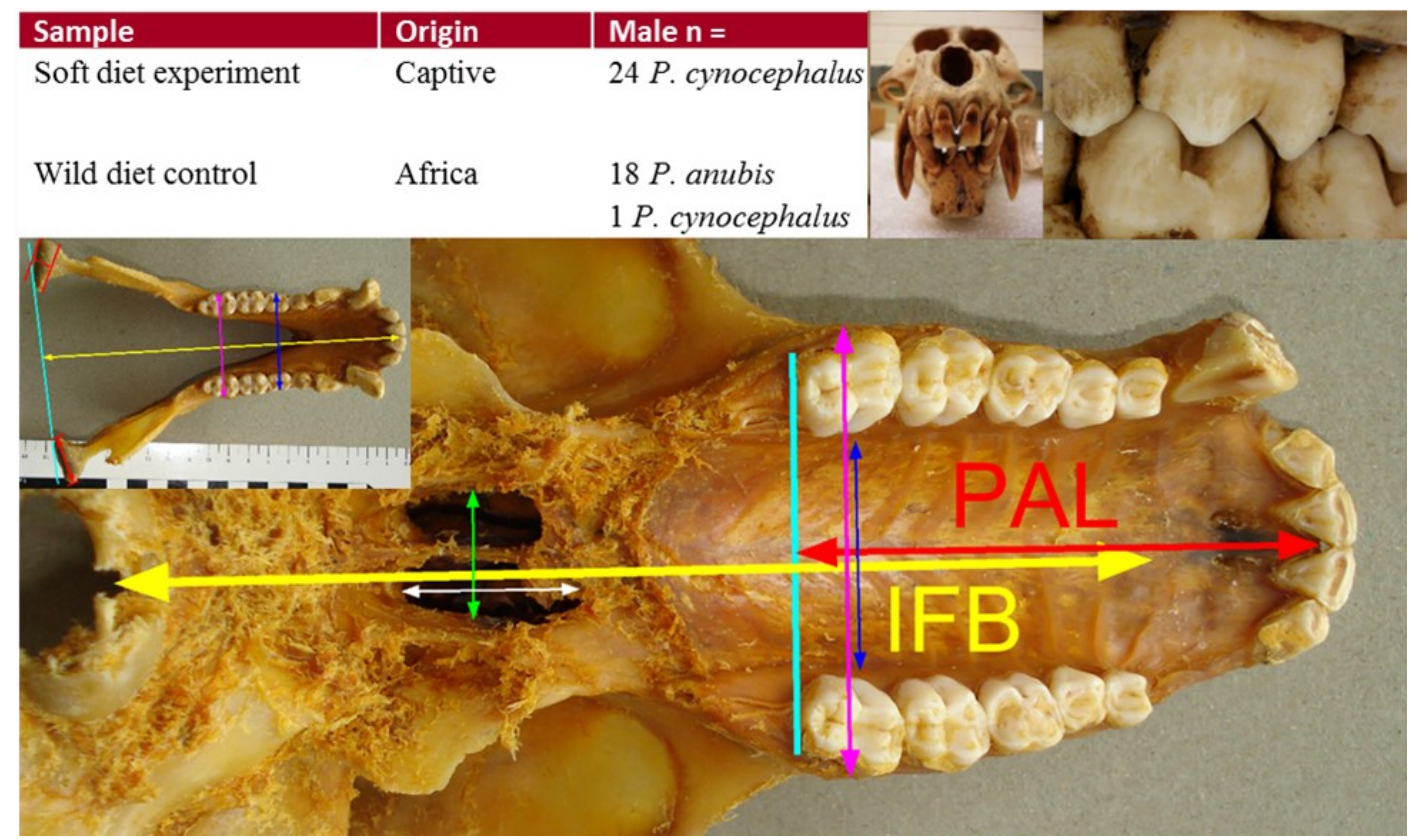

Fig. 1. Illustration of relevant linear measures, palate length (PAL) and incisivion to basion (IFB). 
TABLE 1. Metric variables

\begin{tabular}{|c|c|}
\hline Measure & Description \\
\hline MWCond & Mediolateral width of the mandibular condyle taken at the longest ML axis \\
\hline MLCond & Maximum AP length of the mandibular condyle, perpendicular to MWCond \\
\hline $\mathrm{MDC}$ & Maximum depth of the mandibular corpus from the superior edge of the alveolar \\
\hline MWCorp & $\begin{array}{l}\text { Maximum width of the mandibular corpus from the labial to lingual side of the mandibular cor- } \\
\text { pus at the midpoint of M1 }\end{array}$ \\
\hline MMdW & $\begin{array}{l}\text { Maximum mandibular arch width at M1 taken on alveolar bone with calipers at the midpoint of } \\
\text { LM1 and RM1 }\end{array}$ \\
\hline NMdW & $\begin{array}{l}\text { Minimum mandibular arch width at M3 taken on the alveolar bone with calipers at the mid- } \\
\text { point of LM3 and RM3 }\end{array}$ \\
\hline MandL & $\begin{array}{l}\text { Mandibular length from the anterior point of projection on the alveolar bone of the mandible to } \\
\text { the most posterior projection of the mandibular condyles (infradentale to condylion) }\end{array}$ \\
\hline MMW & $\begin{array}{l}\text { Maximum maxillary arch width taken at the widest point of the alveolar bone on the maxilla } \\
\text { regardless of field or adjacent tooth }\end{array}$ \\
\hline NMW & $\begin{array}{l}\text { Minimum maxillary arch width at M3 taken on the alveolar bone (lingual surface) at the mid- } \\
\text { points of LM3 \& RM3 }\end{array}$ \\
\hline NSB & Minimum snout breadth between L \& R maxilla, with calipers in the fossae \\
\hline PAL & $\begin{array}{l}\text { The length of the palate measured from prosthion to the plane of the posterior projection of the } \\
\text { maxilla (using a rubber band to delineate the posterior border) }\end{array}$ \\
\hline IFB & $\begin{array}{l}\text { From the most posterior point on the incisive foramen to basion (incisivion was estimated } \\
\text { in poorly mascerated soft-diet individuals) }\end{array}$ \\
\hline PAB & $\begin{array}{l}\text { The greatest medio-lateral breadth of the posterior airway, taken with the calipers held just pos- } \\
\text { terior to the palate }\end{array}$ \\
\hline PAH & $\begin{array}{l}\text { The anterio-posterior length of the internal nares, from the posterior margin of the palate to the } \\
\text { anterior margin of the opening }\end{array}$ \\
\hline BZB & The widest breadth across L \& R zygomatic arches (zygion to zygion) \\
\hline FB & The breadth of the frontal bone across brows \\
\hline FMW & $\begin{array}{l}\text { The medio-lateral breadth of the foramen magnum, measured from within the margins of the } \\
\text { occipital with the "inside" arms of the caliper }\end{array}$ \\
\hline
\end{tabular}

PC 2 is not the result of genetic differences.

A two-sample $t$-test demonstrates that mean differences in PAL were significantly smaller $(\mathrm{P}<0.000)$, and an F statistic indicates that IFB was significantly more variable $(\mathrm{p}<0.010)$ in the soft-diet sample (Fig. 4, Table 3). Again, the bivariate plot of PAL and IFB (Fig. 5) implies that the wild$\operatorname{diet} P$. cynocephalus individual groups with the wild-diet $P$. anubis group, as a this is a reflection of the PCA measures responsible for driving the observed variation. Although a Pearson's correlation coefficient for the soft-diet group $(\mathrm{r}=0.752)$ was only slightly lower than the wild-diet sample $(\mathrm{r}=0.780)$, results suggest that the soft-diet sample displays significantly shorter palate lengths relative to IFB distances. A Mann-Whitney U test (Table 4) indicates that the softdiet sample exhibits significantly greater overall occlusal scores than the wild-diet group. Spearman's correlation coefficient (Table 5) demonstrates a relatively weak yet significant $(\mathrm{p}<0.050)$ negative correlation between PAL and occlusal scores and suggests that occlusal patterns become more variable as palate length reduces.

\section{DISCUSSION}

The hypothesis that the soft-diet baboon sample would exhibit higher levels of craniofacial variation due to decreased masticatory loading during ontogeny is supported. Specifically, the soft-diet group exhibits greater occlusopalatal variation. The single wild-diet $P$. cynocephalus offers support that our results are not the mere reproduction of clinal shape differences of genus Papio as noted by Frost et al. (2003). Although genetics undoubtedly play a considerable role (Carlson, 2005; Harris, 2008; Koussoulakou et al., 2009), our study supports the potential for environmental factors to alter developmental trajectories.

Incisivion (Mew, 1974; Frost et al., 2003) should be utilized when investigating basicranial flexion. By using incisivion to construct multivariate ratios, it may be possible to test for the functional and taxonomic significance of the palate's effect on basicranial flexion (Corruccini, 1978; Oxnard, 1983). Through dietary manipulation of living animals, radiographs could be used to investigate the relationships between ontogenetic shape changes, adult cranial form, allometric scaling, heterochrony, and differential 
TABLE 2. Occlusal variables

\begin{tabular}{|c|c|}
\hline Measure & Description \\
\hline Anterior Overjet & $\begin{array}{l}\text { The maximum distance between the most inferior point on the upper central } \\
\text { incisors, and the most superior point on the lower central incisors }\end{array}$ \\
\hline Anterior Overbite & $\begin{array}{l}\text { The maximum distance between the labial surface of the lower central inci- } \\
\text { sors and the labial surface of the upper central incisors }\end{array}$ \\
\hline Posterior Crossbite & $\begin{array}{l}\text { The buccolingual interrelationship between upper and lower first molar an- } \\
\text { tagonists }\end{array}$ \\
\hline Normal occlusion & $\begin{array}{l}\text { The buccal cusp of the upper molars overhang the lower buccal cusps, with } \\
\text { the lowers reaching proper centric occlusion }\end{array}$ \\
\hline Buccal crossbite & $\begin{array}{l}\text { The upper molars are atypically buccally located, such that the lowers do not } \\
\text { reach proper centric occlusion }\end{array}$ \\
\hline Lingual crossbite & $\begin{array}{l}\text { The upper molars are atypically lingual, such that the buccal cusps of the up- } \\
\text { pers do not overhang the lowers }\end{array}$ \\
\hline Buccal Segment Relationship & $\begin{array}{l}\text { The interrelationships between the upper and lower first molars in the para- } \\
\text { sagittal plane }\end{array}$ \\
\hline Class 1 & The mesiobuccal cusp of the M1 is parasagittal to the buccal groove of M1 \\
\hline Class 2 & The mesiobuccal cusp of M1 is mesial to the buccal groove of M1 \\
\hline Class 3 & The mesiobuccal cusp of M1 is distal to the buccal groove of M1 \\
\hline Rotation & $\begin{array}{l}\text { Refers to a tooth in its normal position in the dental arcade but rotated about } \\
\text { its long axis. The sum of rotated teeth are recorded for each side. Recorded } \\
\text { for both maxilla and mandible }\end{array}$ \\
\hline 0 & Unrotated \\
\hline 1 & Rotated $<45^{\circ}$ \\
\hline 2 & Rotated $>45^{\circ}$ \\
\hline Displacement & $\begin{array}{l}\text { Refers to a tooth that is out of ideal alignment. The summed value is record- } \\
\text { ed. Recorded for both maxilla and mandible }\end{array}$ \\
\hline 0 & Not displaced \\
\hline 1 & Displaced $<2 \mathrm{~mm}$ \\
\hline 2 & Displaced $>2 \mathrm{~mm}$ \\
\hline
\end{tabular}

growth (Frost et al., 2003; Leigh, 2006; Trenouth and Joshi, 2006). This could broaden allometric understanding, as Gilbert (2011) reminds us that a large percentage of shape information is lost during allometric correction, and our results suggest that masticatory behavior also confounds shape analyses.

These implications are also important for humans. Many authors have used the hunter-gatherer/agricultural transition to illustrate how changes in dietary selective pressures produced skull morphologies able to cope with new masticatory functional demands (Carlson, 1976a, b; Carlson and Van Gerven, 1977; Hinton and Carlson, 1979; Paschetta et al., 2010). Clinically, Haskell et al. (2009) noted correlations between snoring, sleep apnea, and the structures of the face and mouth. However, this study cannot conclude about the taxonomic significance of airway dimensions in the two samples specifically, nor the relationships between dental variation and airway dimensions in general. There could be multiple reasons why smaller airway dimensions were not found in the soft-diet group. Although the tight confines of the airway's location could have prevented the caliper arms from accurately touching the landmarks, there also exists the possibility that there does not exist significant morphological differences in this area.

Anthropologically, it should be remembered that diet influences our reconstructions of biodistance, phylogeny, and taxonomy whether we account for it or not. Eshed et al. (2006) and Halcrow et al. (2013) rightfully remind us that simple linear relationships between diet and the denti- 


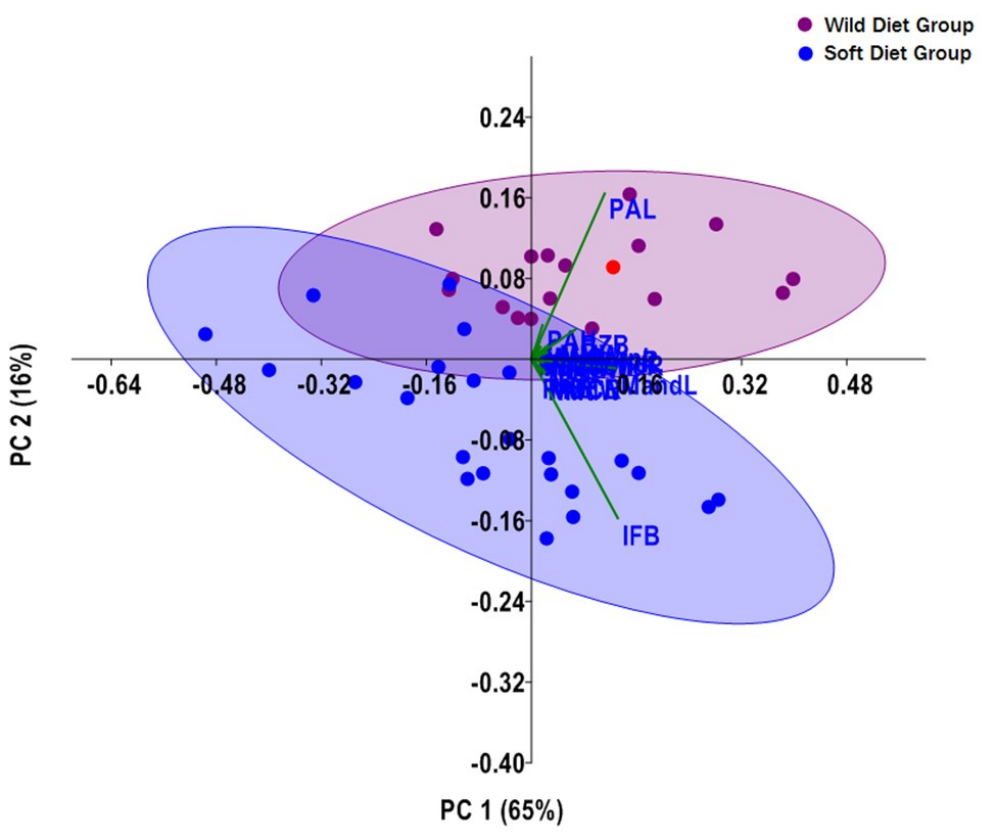

Fig. 2. PCA on scaled data. Maroon circles = wild diet sample; blue circles = soft diet sample; red circle $=$ the single wild-diet P. cynocephalus.

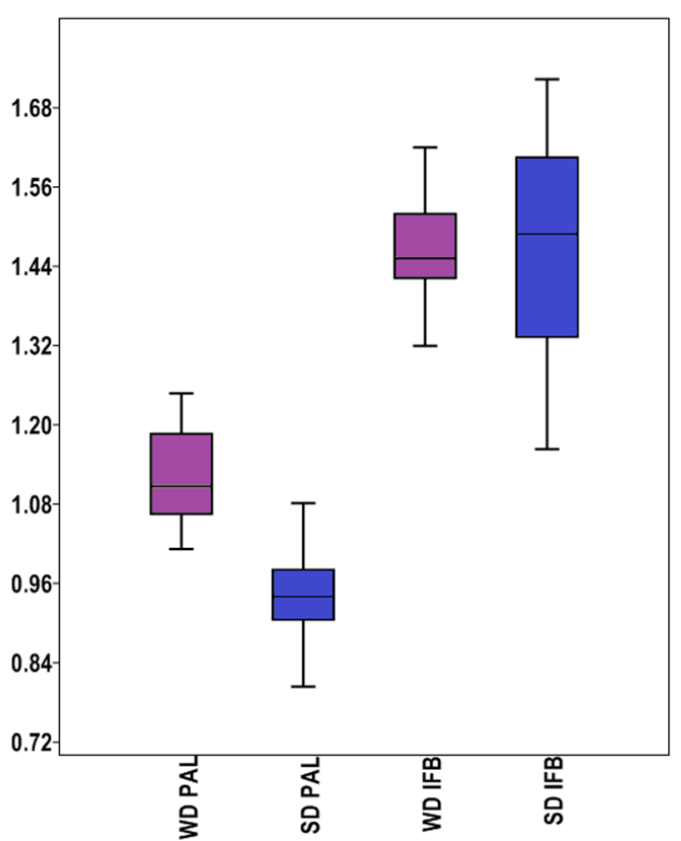

Fig. 4. Boxplot for scaled data. $\mathrm{WD}=$ wild-diet sample; $\mathrm{SD}=$ soft-diet sample. $\mathrm{PAL}=$ palate length; IFB = incisivion to basion.
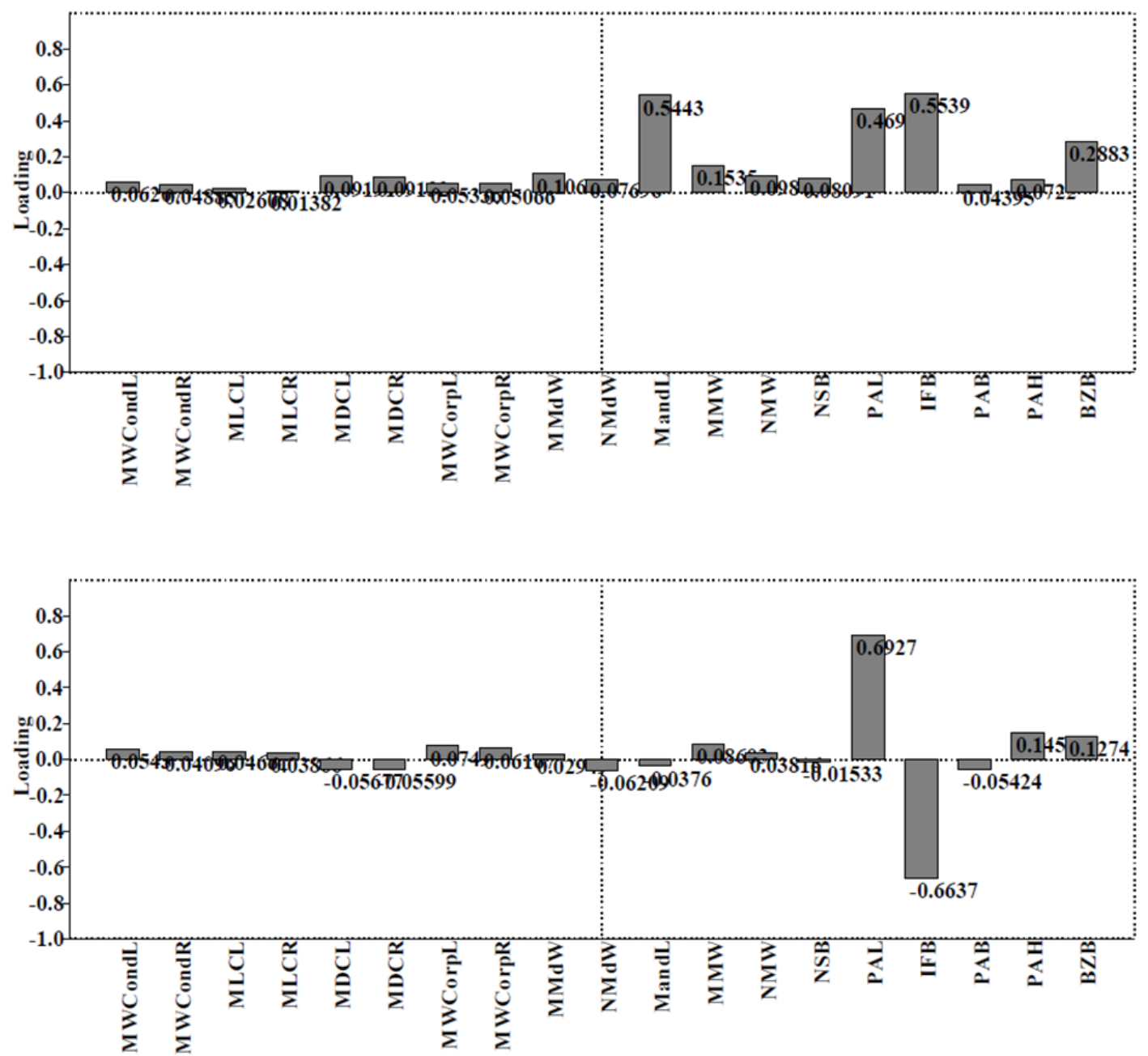

Fig. 3. Loadings for PC1 (top) and PC2 (bottom). Note the inverse relationship between PAL and IFB for PC2. 
tion should not be assumed as the ambiguity of genetic, environmental, and cultural influences have the potential to produce a multitude of skeletal adaptations and alterations. By expanding on the research of Corruccini and Beecher (1984), we were able to demonstrate that a variety of research designs can strengthen discussions about the gene-environment interaction and other complex anthropological topics. Luckily, a stronger understanding of genetic influences will better contextualize environmental factors of phenotypic variation. Kuang et al. (2013) have documented the involvement of regulatory genes in mice with long-term, laboratory induced malocclusions. New discoveries such as this continue to enable anthropology to pioneer explanations of observed skeletal variation.

\section{ACKNOWLEDGEMENTS}

Our gratitude is owed to Bill Stanley, Lawrence Haney, and Anna Goldman at the Field Museum of Natural History (Division of Mammals) for access to the wilddiet sample. Thanks to the Southern Illinois University Carbondale Department of Anthropology for providing the soft-diet sample. Jeremiah E. Scott is thanked for providing helpful comments on the manuscript.

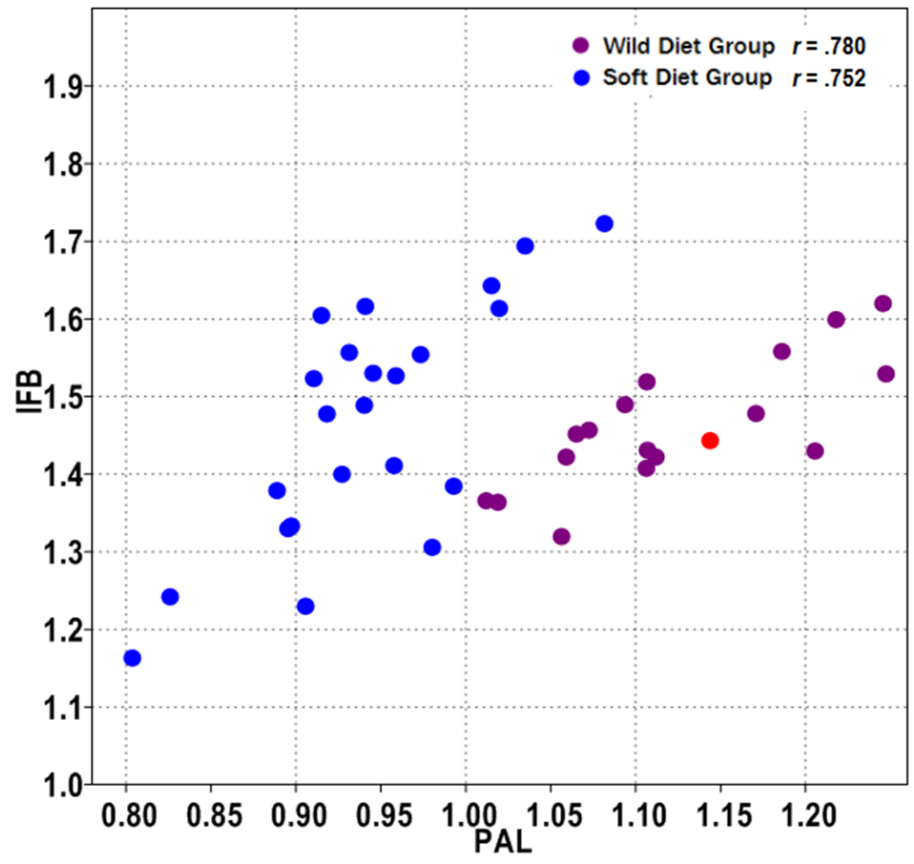

Fig. 5. Biplot showing the relationship between PAL and IFB. Maroon circles $=$ wild-diet sample; blue circles $=$ soft-diet sample; red circle $=$ the single wild-diet $P$. cynocephalus.

TABLE 3. Summary statistics for relevant linear measurements scaled for body size

\begin{tabular}{llllllll}
\hline & $\mathrm{n}$ & $\overline{\mathrm{x}}$ & $\mathrm{SD}$ & $\mathrm{F}$ & $p$ & $\mathrm{t}$ & $p$ \\
\hline PAL WD & 18 & 1.12 & 0.07 & 1.35 & 0.500 & 8.49 & $2.16 \mathrm{E}-10^{* *}$ \\
PAL SD & 23 & 0.94 & 0.06 & & & & \\
IFB WD & 18 & 1.46 & 0.08 & 3.668 & $0.008^{*}$ & -0.13 & 0.90 \\
IFB SD & 23 & 1.47 & 0.15 & & & & \\
\hline
\end{tabular}

*significant at $\mathrm{P}<0.010, * *$ significant at $\mathrm{p}<0.000 ; \mathrm{WD}=$ wild-diet sample, $\mathrm{SD}=$ soft-diet sample; $\mathrm{PAL}=$ palate length, IFB = incisive foramen to basion

TABLE 4. Mann-Whitney U Test for wild-diet and soft-diet occlusal scores

\begin{tabular}{lllll}
\hline & $\mathrm{n}$ & Median & $\mathrm{U}$ & $p$ \\
\hline Occlusal WD & 19 & 0 & 122 & $0.035^{*}$ \\
Occlusal SD & 20 & 1 & & \\
\hline
\end{tabular}

*significant at $\mathrm{p}<0.050$

TABLE 5. Spearman correlation for relevant linear measures and occlusal scores

\begin{tabular}{lll}
\hline & r's & $p$ \\
\hline PAL + Occlusal & -0.3782 & $0.017^{*}$ \\
IFB + Occlusal & -0.2260 & 0.172 \\
\hline
\end{tabular}

${ }^{*}$ significant at $\mathrm{p}<0.050$ 


\section{LITERATURE CITED}

Akosim C, Joseph J, Egwumah PO. 2010. Assessment of feeding behavior of baboons (Papio anubis) in Hong Hills Adamawa State, Nigeria. J Res Forest Wldl Env 2:60-72.

Alberts SC, Altmann S. 2001. Immigration and hybridization patterns of yellow and anubis baboons in and around Amboseli, Kenya. Am J Primatol 53:139-154.

Angle EH. 1899. The classification of malocclusion. Dent Cosmos 41:248-264.

Barton RA. 1993. Sociospatial mechanisms of feeding competition in female olive baboons, Papio anubis. Anim Behav 46:791-802.

Beecher RM, Corruccini RS. 1981a. Effects of dietary consistency on craniofacial and occlusal development in the rat. Angle Orthod 51:61-69.

Beecher RM, Corruccini RS. 1981b. Effects of dietary consistency on maxillary arch breadth in macaques. J Dent Res 60:68.

Carlson DS. 1976a. Temporal variation in prehistoric Nubian crania. Am J Phys Anthropol 45:467-484.

Carlson DS. 1976b. Patterns of Morphological Variation in the Human Midface and Upper Face. In: McNamara JA, editors. Factors affecting the growth of the midface: Proceedings of a sponsored symposium honoring professor Robert E. Moyers, held February 6 and 7 in Ann Arbor, Michigan. Ann Arbor: Center for Human Growth and Development. p 277-279.

Carlson DS, Van Gerven DP. 1977. Masticatory function and post-Pleistocene evolution in Nubia. Am J Phys Anthropol 46:495-506.

Carlson DS. 2005. Theories of craniofacial growth in the postgenomic era. Semin Orthod 11:172-183.

Charpentier MJE, Tung J, Altmann S, Alberts SC. 2008. Age at maturity in wild baboons: Genetic, environmental, and demographic influences. Mol Ecol 17:2026-2040.

Corruccini RS. 1978. Morphometric analysis: uses and abuses. Yrbk Phys Anthropol 21:134-150.

Corruccini RS. 1984. An epidemiologic transition in dental occlusion in world populations. Amer J Orthodontics 86:419-426.

Corruccini RS. 1999. How anthropology informs the orthodontic diagnosis of malocclusion's causes. Lewiston: Edwin Mellen Press.

Corruccini RS, Beecher RM. 1982. Occlusal variation related to soft diet in a nonhuman primate. Science (New Series) 218:74-76.

Corruccini RS, Potter RHY, Dahlberg AA. 1983. Changing occlusal variation in Pima Amerinds. Am J Phys Anthropol 62:317-324.

Corruccini RS, Beecher RM. 1984. Occlusofacial morphological integration lowered in baboons raised on soft diet. J Cran Genet Dev Bio 4:135-142.
Corruccini RS, Lee GTR. 1984. Occlusal variation in Chinese immigrants to the United Kingdom and their offspring. Arch Oral Biol 29:779-782.

Dias GJ, Cook RB, Mirhosseini M. 2011. Influence of food consistency on growth and morphology of the mandibular condyle. Clin Anat 24:590-598.

Eshed V, Gopher A, Hershkovitz I. 2006. Tooth wear and dental pathology at the advent of agriculture: New evidence from the Levant. Am J Phys Anthropol 130:145-159.

Evensen JP, Øgaard B. 2007. Are malocclusions more prevalent and severe now? A comparative study of medieval skulls from Norway. Am J Orthod Dentofac 131:710-716.

Frost SR, Marcus LF, Bookstein FL, Reddy DP, Delson E. 2003. Cranial allometry, phylogeography, and systematics of large-bodied Papionins (Primates: Cercopithecinae) inferred from geometric morphometric analysis landmark data. Anat Rec Part A 275A: 10481072.

Gilbert CC. 2011. Phylogenetic analysis of the African Papionin basicranium using 3-D geometric morphometrics: The need for improved methods to account for allometric effects. Am J Phys Anthropol 144:60-71.

Gould SJ. 1975. Allometry in primates, with emphasis on scaling and the evolution of the brain. In: Szalay FS, editor. Approaches to Primate Paleobiology. Basel: S. Karger. p 244-292.

Grünheid T, Brugman P, Zentner A, Langenbach GEJ. 2009. Changes in rabbit jaw-muscle activity parameters in response to reduced masticatory load. J Exp Biol 213:775-781.

Halcrow SE, Harris NJ, Tayles N, Ikehara-Quebral R, Pietrusewsky M. 2013. From the mouths of babes: Dental caries in infants and children and the intensification of agriculture in mainland Southeast Asia. Am J Phys Anthropol 150:409-420.

Hammer Ø, Harper DAT, Ryan PD. 2001. Past: Paleontological Statistics Software Package for Education and Data Analysis. Palaeontol Electron 4:, vol. 4, issue 1, a r t . 4:9 p p , $178 \mathrm{~kb} . \mathrm{ht} \mathrm{tp://pala} \mathrm{e} \mathrm{o-}$ electronica.org/2001_1/past/issue1_01.htm.

Harris EF. 2008. Interpreting heritability estimates in the orthodontic literature. Semin Orthod 14:125-134.

Harris EF, Corruccini RS. 2008. Quantification of dental occlusal variation: A review of methods. Dental Anthropology 21:1-11.

Haskell JA, McCrillis J, Haskell BS, Scheetz JP, Scarfe WC, Farman AG. 2009. Effects of Mandibular Advancement Device (MAD) on airway dimensions assessed with cone- beam computed tomography. Sem Orthod 15:132-158.

Hinton RJ, Carlson DS. 1979. Temporal changes in human temporomandibular joint size and shape. Am J Phys Anthropol 50:325-333. 
Jašarević E, Ning J, Daniel AN, Menegaz RA, Johnson JJ, Stack MS, Ravosa MJ. 2010. Masticatory loading, function, and plasticity: A microanatomical analysis of mammalian circumorbital soft-tissue structures. Anat Rec 293:642-650.

Johnson CA, Sweddell L, Rothman JM. 2012. Feeding ecology of olive baboons (Papio anubis) in Kibale National Park, Uganda: preliminary results on diet and food selection. Afr J Ecol 50:367-370.

Koussoulakou DS, Margaritis LH, Koussoulakou SL. 2009. A curriculum vitae of teeth: Evolution, generation, regeneration. Int J Biol Sci 5:226-243.

Kuang B, Dai J, Wang QY, Song R, Jiao K, Zhang J, Tian XG, Duan YZ, Wang MQ. 2013. Combined degenerative and regenerative remodeling responses of the mandibular condyle to experimentally induced disordered occlusion. Am J Orthod Dentofac 143:69-76.

Larsson E, Øgaard B, Lindsten R, Holmgren N, Brattberg M, Brattberg L. 2005. Craniofacial and dentofacial development in pigs fed soft and hard diets. Am J Orthod Dentofac 128:731-739.

Leigh SR. 2006. Cranial ontogeny of Papio baboons (Papio hamadryas). Am J Phys Anthropol 130:71-84.

Makedonska J, Wright BW, Strait DS. 2012. The effect of dietary adaptation on cranial morphological integration in capuchins (Order Primates, Genus Cebus). PLoS ONE 7 (10): e40398. doi:10.1371/ journal.pone. 0040398

Mew JRC. 1974. The incisive foramen - A possible reference point. Br J Orthod 1:143-146.

Moore-Jansen PH, Ousley SD, Jantz RL. 1994. Data collection procedures for forensic skeletal material. Report of investigation no. 48. Department of Anthropology. Knoxville: The University of Tennessee.

Oxnard CE. 1983. Multivariate statistics in physical anthropology: testing and interpretation. Z Morphol Anthropol 73:237-278.

Paschetta C, de Azevedo S, Castillo L, MartínezAbadías N, Hernández, Lieberman DE, GonzálezJosé R. 2010. The influence of masticatory loading on craniofacial morphology: A test case across technological transitions in the Ohio Valley. Am J Phys Anthropol 141:297-314.

Phillips-Conroy JE, Jolly CJ. 1988. Dental eruption schedules of wild and captive baboons. Am J Primatol 15:17-29.

Post DG. 1981. Activity patterns of yellow baboons (Papio cynocephalus) in the Amboseli National Park, Kenya. Anim Behav 29:357-374.

R Core Team. 2013. R: A language and environment for statistical computing. R Foundation for Statistical Computing. Vienna, Austria. http://www.Rproject.org

Radinsky LB. 1967. Relative brain size: A new measure.
Science 155:836-838.

Ravosa MJ, Ning J, Costley DB, Daniel AN, Stock SR, Stack MS. 2010. Masticatory biomechanics and masseter fiber-type plasticity. J Musculoskelet Neuronal Interact 10:46-55.

Samuels A, Altmann J. 1986. Immigration of a Papio anubis male into a group of Papio cynocephalus baboons and evidence for an anubis-cynocephalus hybrid zone in Amboseli, Kenya. Int J Primatol 7:131138.

Trenouth MJ, Joshi M. 2006. Proportional growth of craniofacial regions. J Orofac Orthop 67:92-104.

Tung J, Charpentier MJE, Garfield DA, Altmann J, Alberts SC. 2008. Genetic evidence reveals temporal change in hybridization patterns in a wild baboon population. Mol Ecol 17:1998-2011.

Varrela J. 1990. Effects of attritive diet on craniofacial morphology: A cephalometric analysis of a Finnish skull sample. Eur J Orthod 12:219-223.

Varrela J. 1992. Dimensional variation of craniofacial structures in relation to changing masticatoryfunctional demands. Eur J Orthod 14:31-36.

Varrela J. 2006. Masticatory function and malocclusion: A clinical perspective. Semin Orthod 12:102-109.

Wahungu GM. 1998. Diet and habitat overlap in two sympatric primate species, the Tana crested mangabey Cercocebus galeritus and yellow baboon Papio cynocephalus. Afr J Ecol 36:159-173.

Williams-Blangero S, Vandeberg JL, Blangero J, Konigsberg L, Dyke B. 1990. Genetic differentiation between baboon subspecies: Relevance for biomedical research. Am J Primatol 20:67-81.

Zinner D, Wertheimer J, Liedigk R, Groeneveld LF, Roos C. 2013. Baboon phylogeny as inferred from complete mitochondrial genomes. Am J Phys Anthropol 150:133-140. 